\title{
O PÉ EM QUE ANDA O BYRON COXO NO BRASIL DA TRADUÇÃO: COM DON JUAN
}

\section{Lucas de Lacerda Zaparolli de Agustini}

\section{Introdução}

Decerto se sabe que lorde Byron é um prato cheio no âmbito dos Estudos da Tradução. Porém poucas pessoas, como Onédia Célia de Carvalho Barboza e Daniel Lacerda, com suas teses acerca do libertino inglês, refestelaram-se nesse prato cheio. $\mathrm{O}$ que doravante será dito provará ser mais que um prato cheio, será um banquete.

É grande acerto dizer que as poesias líricas byronianas, bem como a narrativa do jovem Childe Harold, reinaram supremas no imaginário artístico ocidental na maior parte do século XIX. Basta dar-se à surpresa de, em History of the Western Philosophy, do Nobel Bertrand Russel, deparar-se com o nome Byron entre Kant, Hegel, Schopenhauer e Nietzsche. Mesmo Goethe chamou-lhe o maior nome do século. Foi o "rei dos românticos", não resta dúvida. E na quarta parte da obra machadiana aparece a marca Byron, com muita ironia.

Tudo isso diz bastante, mas nada acerca da obra-prima épico-satírica dele, o Don Juan. Onédia constata o temor por essa obra gigante, "que sempre intimidou os franceses" do seguinte modo: "entre as traduções francesas parciais, na bibliografia fornecida pela edição de John Murray das obras completas de Byron, constam 3 de Don Juan para 10 de Childe Harold" (Barbosa, 1975, p. 19). Sendo assim, acrescenta-se que, se o todo o Byron, morto em 1824, possuía duas traduções de suas obras completas para o francês em 1830 - e o Don Juan por Amedée Pichot e por Paulin Paris - aqui no Brasil, onde estamos, quase 200 anos depois de sua morte, ainda um pouco longe da tradução de toda sua obra, incluindo suas apetitosas cartas, então:

1) Qual é, como é e onde se situa o banquete da tradução byroniana?

2) O que se tem do Don Juan e das outras obras da maturidade na última flor do Lácio?

3) Como foram cometidas essas traduções? 
AGUSTINI - O pé em que anda o Byron coxo no Brasil da tradução...

Logo tudo será respondido, mas adianta-se desde já que a melhor parte deste artigo, seu mais saboroso acepipe, é a tradução de Décio Pignatari analisada no capítulo 4, onde também se explica o título deste papel.

\section{Byron (satírico) no Brasil (romântico)}

Toda a obra traduzida de Byron para o português entre o período de 1832 e 1911 encontra-se devidamente levantada e comentada em Byron no Brasil: traduções, a tese da supracitada Onédia, pupila de Antonio Candido. Usando a teoria de tradução do comparatista norte-americano Harry Levin, seu trabalho não se limita só às "traduções", mas trata também das "paráfrases", das "adaptações — em que o original é aclimatado ao gosto e sensibilidade do adaptador", e das "imitações - em que o texto original serve apenas de modelo, e geralmente em um de seus aspectos parciais" (Barbosa, 1975, p. 31), ou, para usar o pensamento já consagrado de Paulo Henriques Britto, isto é "uma espécie de interferência na obra alheia que resulta num poema novo" (Britto, apud Faleiros, 2012, p. 60).

Ali estão mesmo todas as traduções efetuadas de Byron por todos os poetas românticos brasileiros conhecidos, como Álvares de Azevedo, Castro Alves, Pinheiro Guimarães, Francisco Otaviano, Barão de Paranapiacaba; por outros menos conhecidos, como Antônio Tibúrcio Craveiro, Teófilo Dias, João Júlio dos Santos; e por outros ainda mais ignotos, como José Carlos de Almeida Areias e pelo próprio irmão de Castro Alves, que assinava sob o pseudônimo de Alberto Krass, sem contar alguns dos quais quase nada se sabe, como é o caso do tradutor que se diz chamar J. Luz.

Deixa-se explicitado aqui que a maior parte dessas traduções foi feita dos poemas de Byron dos quais melhor se depreende a ideia de mal byrônico, isto é, o gosto pela morte e languidez que caiu no capricho dos mancebos citados acima, como em "To Inez", em "Fare Thee Well”, em "To a Lady", e mais ainda em "Lines Inscribed upon a Cup Formed from a Skull” e em "Darkness". Resta lembrar que Cardoso de Meneses, o Barão de Paranapiacaba, traduziu também quase todos os tales de Byron, em alexandrinos que dão a impressão de ter vinte sílabas, ao menos o é assim em Parisina e Mazzepa, conquanto $O$ Corsário seja uma tradução que veio muito bem a calhar, isso em relação à forma e à dicção do original, que é composto em dístico heroico e possui tom pomposo, ambos bem ecoados nos alexandrinos da tradução do Barão de Paranapiacaba, que igualmente "soa pomposa e artificial” (Barbosa, 1975, p. 244). 
Fato curioso é ter sido aquele mesmo tal de J. Luz do qual nada se conhece, o primeiro a publicar algum trecho traduzido da obra magna de Byron, o Don Juan, em 1875, no fabuloso "Jornal das Famílias". Intitulou sua tradução - de uma canção do Don Juan interpolada no Canto XVI — de “O Monge Negro”. Essa canção, de quase 50 versos, nada tem da sátira menipeia escrita na oitava-rima que é o tom principal dos outros mais de dezesseis mil versos. Do mesmo modo, os decassílabos soltos da tradução nada possuem da musicalidade que é própria à canção original, toda composta em sonoros tetrâmetros e trímetros anapésticos rimando ABABCBCB. Sem contar, claro, que a tradução foi feita calcada na tradução para o francês em prosa de Louis Barré, como se pode depreender claramente dos trechos que seguem:

\author{
Though he came in his might, with King Henry's right, \\ To turn church lands to lay, \\ With sword in hand, and torch light \\ Their walls, if they said nay.
}

De par la volonté du roi Henri, il vient avec toutes ses forces faire des biens de l'église as propriété laïque; armé du glaive et de la torche, il renversera les murs si quelqu'un lui resiste.

Ordens do rei Henrique executando,

Domínios leigos faz dos bens da igreja;

Da espada e do brandão armado, os muros

Pretende destruir, caso resistam.

(Barbosa, 1975, p.234)

"Resistir" e "bens da igreja" realmente não deixam dúvidas. Enfim, para encerrarem-se os comentários acerca da tradução de J. Luz, em se observando os interesses na sátira byroniana deste tradutor, ressalta-se que dele só se sabe uma coisa, e ela é que publicou outra historinha no Jornal das Famílias. Conta de uma senhora enferma com cinco netos, os quais só tinham a avó no mundo, e que, passada a noite de sofrimento intenso, na manhã do dia seguinte:

D’avó sobre o cadáver dormitavam (Barbosa, 1975, p.235). 
AGUSTINI - O pé em que anda o Byron coxo no Brasil da tradução...

"Uma história bem tétrica", sem dúvida, comenta Onédia, e deveras modelar a respeito da imagem de Byron que se buscou criar a todo custo no Brasil, para as famílias (que liam), nos idos fins do século XIX.

Adiante, em 1925, publicou-se o volume das obras completas de Francisco Otaviano em homenagem ao centenário de seu nascimento, e cabe dizer aqui que ele foi um poeta, e profícuo tradutor, muito bem considerado em seu tempo, elogiado por Sílvio Romero e por Machado de Assis, como se lembra Onédia. Lá se depara com o trecho intitulado o "Crepúsculo da Tarde", uma tradução das oitavas CI a CVI do Canto III do Don Juan, que a estudiosa da obra byroniana considera "um belo poema, mas como tradução é uma 'belle infidèle"” (1975, p.140). Ali estão seis estrofes em oitavarima, quarenta e oito versos, que viram setenta na tradução.

Onédia alega que Francisco Otaviano "achou difícil, talvez" e por isto não traduziu a oitava CVI, embora a segunda estrofe da tradução seja "de sua exclusiva responsabilidade" (Barbosa, 1975, p.139). Soma-se que muitas outras coisas são, por assim dizer, do próprio estro lírico de Otaviano interferindo na poesia byroniana, embora em nenhum momento isto tire o valor poético lírico e imagético de suas composições, por assim dizer, tradutórias. Veja-se, como exemplo:

Sweet Hour of Twilight! - in the solitude

Que vira:

Hora doce do trêmulo crepúsculo,

onde "trêmulo" é, como "lânguido", vocábulo chave no lugar-comum do esvaecimento romântico e não deveria faltar jamais numa "tradução de Byron" daquele período, ainda que Byron não o use neste momento específico, ou, às vezes, diga-o em caráter de zombaria. Mais uma vez, é necessário ser dito, "O Crepúsculo da Tarde" é realmente um belo poema, possui aquele cismar romântico entre anões e menestréis, árabes, bailarinas e Juan e Haydea na Ave-Maria do arrebol.

Belo, de fato, mas ainda nada representante da sátira ferina que constitui o extremo oposto do Childe Harold, que é o Don Juan depreendido como um todo, ao 
AGUSTINI - O pé em que anda o Byron coxo no Brasil da tradução...

qual se convencionou tratar como anti-byrônico, e que só apareceria em língua portuguesa no século XX.

Essa foi a salada da entrada, agora vem o prato principal.

\section{Byron no Brasil (militar): caretas de Don Juan, heroísmo e afins}

Pouco antes do "sol que em desmaio no ocidente / bordava o céu de franjas corde-rosa" do "Crepúsculo da Tarde" de Otaviano, publicou-se em Portugal, em 1905, "an extract of 'the immortal poem' by João Vieira” (Sousa, 2004, p.184). Essa mesma tradução viria a ser publicada no Brasil na Série Clássica de Cultura, das Edições Cultura n ${ }^{\circ} 23$, intitulada Obras de Byron, no ano de 1942, sob a direção de José Pérez, que a prefacia referindo-se a Byron em termos tais como "vimo-lo erguer-se, sentimentalmente, de uma vida crapulosa...” (p. XI).

Ali estão as antigas traduções de "O Sonho" por Francisco Otaviano, A Peregrinação de Childe Harold por Pinheiro Guimarães, o Corsário e Manfredo pelo Barão de Paranapiacaba e, finalmente, "Os Amores de D. Juan, extrato do imortal poema de Lord Byron", por João Vieira.

Quem foi João Vieira não se encontrou, como se disse; no livro não há qualquer indicativo das escolhas tradutórias e muito menos quaisquer notas de tradução, ou mesmo qualquer nota de qualquer coisa, daí nada se diz acerca disto por ora, bem como pelas delimitações deste artigo, que se deseja sucinto, conquanto abrangente, e representa apenas um passo inicial no amplo estudo que o autor vem fazendo acerca da poesia e da tradução do multifacetado poeta lorde Byron, para não dizer da própria tradução do Don Juan.

João Vieira traduziu o Don Juan do começo ao fim em prosa. Foi mesmo o único dos tradutores desta obra-prima poética byroniana ao fazê-lo em prosa. Tudo indica ser um tradutor com mais proximidade a Portugal, já que foi publicado ali mais de 30 anos antes. De todo modo, muitas vezes passa batido por dez, vinte, trinta oitavas, não traduzindo delas nenhuma prosaica linha sequer. Mais uma vez, as oitavas que João Vieira finge não ver são justamente as que Byron ironiza, satiriza, critica, e todo o resto que não é apropriado dizer aqui. Mais uma vez, as oitavas escolhidas para serem traduzidas com maior cuidado são aquelas em que Byron narra sua versão para a história de Don Juan, isto é, menos da metade da obra. Tal fato se dá pela questão de, como em A Vida e as Opiniões do Cavalheiro Tristram Shandy, o narrador ser 
AGUSTINI - O pé em que anda o Byron coxo no Brasil da tradução...

autoconsciente e falar mais sobre si e sobre seus pensamentos do que a respeito da história a qual se propôs contar, acabando muitas vezes perdendo-se em divagações, sem que se saiba se retomará ou não o fio da meada.

Do mesmo modo que a obra de Sterne, o Don Juan também é uma obra "inacabada"; costuma-se achar, entretanto, que foi a morte de Byron lutando pela independência da Grécia que o impediu de concluir seu épico-satírico, mas vale lembrar que parou de escrevê-lo quase um ano antes da sua morte e, tendo forças para montar um exército e lutar, não lhas faltariam para dar continuidade em seus versos. Portanto, crê-se que Byron concluiu, sim, sua obra, pois não seria a maior sátira de um épico que precisa de uma "unidade" rigorosa, com início in medias res, meio para falar do começo e fim - um épico sem fim?

Byron traduziu a Ars Poetica de Horácio, de onde tirou a epígrafe para o seu Don Juan, portanto, de cor e salteado tinha conhecimento da estrutura épica, seja dito de passagem.

Está-se, deste modo, falando de uma espécie de obra aberta, que se tornou bastante cara aos modernos e que permite leituras tão díspares, muitas vezes opostas entre si, como o ultra-romântico lânguido e o satírico ferino; o gosto romântico mesmo é caracterizado por esta dicotomia entre o belo e a fera, e quando pode, para acentuar o contraste, acrescenta anões, corcundas e seres como Luzia-Homem. Byron (e nisto Álvares de Azevedo segue-o também) mofa de sua própria página. Como seria distinto disso numa sátira menipeia? Ora, em sua própria origem a sátira menipeia já lida com essa mistura. Mesmo na Antiguidade o filósofo cínico Menipo, criador desse tipo de sátira, era excluído da escola cínica liderada por Diógenes por zombar com sua sátira de todos os vícios e costumes duvidosos, inclusive acerca dos próprios cínicos. Diógenes de Sínope falsificava moedas e havia sido escravo, Menipo era rico criticando a riqueza e, quando a perde, opta, ironicamente, pelo suicídio. É uma zombaria, literalmente, sem fim.

No entanto, após essa digressão, coisa frequente no Don Juan, regressa-se à prosa de João Vieira para ver como o mesmo se isentou de traduzir quase todas as digressões possíveis. E vê-se mais: depois de pular tranquilamente duzentos versos, em sua maior parte satíricos, detém-se cautelosamente sobre a romântica oitava CXIII do Canto II: 
AGUSTINI - O pé em que anda o Byron coxo no Brasil da tradução...

'T was bending close o'er his, and the small mouth

Seemed almost prying into his for breath;

And chafing him, the soft warm hand of youth

Recalled his answering spirits back from Death:

And, bathing his chill temples, tried to soothe

Each pulse to animation, till beneath

Its gentle touch and trembling care, a sigh

To these kind efforts made a low reply.

Que se proseou por:

Estava inclinada sobre ele, e com a sua pequenina boca aproximada à sua, como para interrogar seu hálito, e pouco a pouco, com o doce atrito de sua mão quente, a jovem chamava à vida seus dóceis espíritos. Ela banhava suas fontes geladas e procurava revocar o sangue de suas veias, quando Juan, correspondendo ao doce contacto e inquietos cuidados, agradeceu com um suspiro os generosos esforços da menina. (Byron, 1942, p. 329).

Ainda que em nenhum momento explicitada, evidencia-se facilmente a opção tradutória de João Vieira. Pode-se afirmar sem titubeios que ele realmente traduziu o conteúdo semântico da oitava, conquanto retire de todo a ironia que a conclui, na qual o narrador, depois de muito falar sobre o terno cuidado que com Juan teve a jovem Haida (tradução de João Vieira do nome Haydée, embora não traduza Juan para João), afirma que um suspiro para tanto esforço foi uma resposta bem singela.

Não vale falar de qualquer aspecto sonoro do poema, já que a tradução foi efetuada em prosa.

Há uma coisa, no entanto, que vale a pena apresentar e que destoa de todas as traduções anteriores. Em alguns trechos, João Vieira acrescenta piadinhas do seu próprio e não muito variegado arcabouço, e por sua conta e risco mesmo, como no trecho em que escreve "mas foi pior a emenda do que o soneto" (1942, p. 314), que não possui qualquer paralelo no original.

Vale notar a tradução de temple por "fonte", bem como o termo "menina", também sem paralelo no original, e que não é usual, até onde se sabe, no português de Portugal, onde o coloquial seria "rapariga". Mas, como em nenhum ponto Onédia ou outro estudioso, além do já citado, dão sinais de conhecer essa tradução de João Vieira, e Onédia realmente fez um levantamento exemplar, daí a primeira notícia a se ter dela, a tradução de Vieira, é de ter sido publicada em Portugal em 1905, e em 1942 no Brasil. 
AGUSTINI - O pé em que anda o Byron coxo no Brasil da tradução...

De todo modo, ainda que nestes moldes, está-se diante de um Don Juan em que às vezes se pode sorrir, não se amargurar ad nauseam profundamente de spleen, no maior estilo quanto mais tétrico melhor, conforme a praxe do século XIX entre os jovens do Largo São Francisco, perdidos num desvario funesto pela Pauliceia e pelas orgias macabras daquela pouco ainda estudada "sociedade epicurea".

Não custa lembrar desde já, de passagem, que os tradutores mais recentes do Don Juan, Péricles Eugênio da Silva Ramos, Décio Pignatari e Augusto de Campos, também foram estudantes do Largo São Francisco.

Daí, em 1950, a Coleção Clássicos Jackson relançaria no seu $2^{\circ}$ volume de Poesias, fragmentos da tradução de Parisina por Múcio Teixeira, do Mazeppa, pelo Barão de Paranapiacaba e de "To Inez”, por Francisco Otaviano. As mesmas famosas do século XIX...

Aí vieram os tempos de ditadura, sátira não era muito bem-vinda no caso de um país sisudo como o que aqui se instalou, ainda que a pornochanchada nunca se desenvolvesse tanto, e em 1976 o poeta épico Marcus Accioly lembrava-se com seu Sísifo da peregrinação de lorde Byron, já o herói:

e os meus versos são punhos / que são armas- / brancas / (meu lorde) / com que vou matar-me / ou com as quais vou lutar / em outra guerra / pelos direitos deste hotel / humano / onde escrevi na ficha a minha idade: / cem anos / (de poeta / e de corsário)

como corsários / indo para a morte / poetas somos à vida condenados / (não há outra opção / senão a luta / que prolonga a existência após o risco) / eu e você / meu lorde / eu o de ontem / você o de amanhã) / somos os mesmos / que importa a glória das canções / que importam nossos nomes na vala / dos sem nomes? (Accioly, 1976, p. 230)

Poder-se-iam dizer belos versos de guerrilha, feitos na época da luta armada pela liberdade, que hoje foi relativamente conquistada, e segue mal-usada, mas que em regime militar mal se podia ver a cor.

Depois, em 1988, José Lino Grünnewald publica suas traduções dos mesmos poemas ultra-românticos de Byron em mais uma antologia.

E, finalmente, em 1989 o Byron adulto vem para o português!

O poeta da Geração de 45, Péricles Eugênio da Silva Ramos, publica Poesias de Lorde Byron, onde traduz “To Inez", "Darkness" etc, juntamente com dois trechos do Don Juan. Seguindo a tendência traduzir as canções do Don Juan e não ele mesmo, 
desta vez, aproveitando o Byron heroico, logrou-se passar para vernáculo "As Ilhas da Grécia" (Byron, 1989, p. 26), hino de amor a este país que era escravizado pelos turcos, interpolado no Canto III, oitava LXXXVI, que é belo, exortativo e emocionante, mas ainda nada da sátira menipeia que, falando sério, dá o tom geral do Don Juan.

No mesmo livro, aí sim, pela primeira vez publicadas em verso português, cinco oitavas do verdadeiro, brilhante e vivaz humor byroniano adentram o sol resplandecente das letras brasileiras e tiram o véu lânguido e abatido do Byron adolescente do ultra-romantismo! São do Canto IV essas benditas oitavas, CVIII a CXII, e receberam como nome "Os Graus do Azul” (1989, p. 113).

Em futuros artigos as traduções serão estudadas detalhadamente; aqui se limita a dizer que a técnica de tradução dessas oitavas é quase original: todos os pentâmetros iâmbicos com rima $\mathrm{ABABABCC}$ tornaram-se alexandrinos, e o esquema rímico não segue regra alguma, muito embora os dísticos finais sempre rimem entre si. Ainda contando com alexandrinos há a supressão de muita coisa. Mas a ideia satírica está muito bem expressa, o que significa um bom começo em se tratando de traduzir uma obra satírica-menipeica no país do futebol e que até então não se havia visto por aqui.

$\mathrm{Na}$ falta de espaço, vai muito bem a calhar o que John Milton observou acerca dos poetas deste período: "é muito mais difícil esquematizar as ideias sobre a tradução da Geração de 45 porque elas nunca explicam certas atitudes que tomam com relação às traduções que fazem" (Milton, 1993, p. 169).

Fica, no mais, um breve exemplo:

An airy instrument, with which he sought

To ascertain the atmospheric state,

By measuring 'the intensity of blue':

Oh, Lady Daphne! let me measure you.

Que se traduz por:

Um aéreo instrumento, para procurar

Do estado da atmosfera se certificar, Medindo os "graus do azul", tal como ele apareça, Deixai portanto, ó Lady Daphne, que eu vos meça!

(Byron, 1989, p.115) 
Inversões sintáticas, transformação do coloquial e leve no pesado alexandrino, a tradução de "you” pelo "vós" y otras cositas más das quais não há espaço para falar aqui.

Adiante. No mesmo 1989, Paulo Henriques Britto publicou a primeira edição da sua tradução de outra obra byroniana dita da maturidade, Beppo - uma história veneziana. Lá, em verdadeira e sonora oitava-rima, com seus tantos cortes assumidos logo no prefácio, e devidamente justificados, e seus enjambements bem encavalgados, estão vertidas as 100 oitavas que compõem esta historieta veneziana, e que abrem caminho para as infindáveis digressões do gigantesco Don Juan. ${ }^{1}$

Em 1998, o poeta Nelson Ascher mete também o dedo no bolo-byron e traduz o último poema que o libertino inglês escreveu sobre a face da terra, "On This Day I complete My thirty-Sixth Year", e o inclui em seu livro Poesia Alheia, 124 poemas traduzidos. Veja-se a penúltima quadra do poema, mais a de Ascher, comparando-a com a mesma feita pelo Barão de Paranapiacaba:

\title{
If thou regret'st thy youth, why live? \\ The land of honourable death \\ Is here:- up to the Field, and give \\ Away thy breath!
}

Que Nelson optou por traduzir fluentemente como:

\author{
Por que viver se tens saudade \\ da juventude? Estás na terra \\ da morte honrosa: solta \\ o alento final na guerra! \\ (Ascher, 1998, p.85)
}

E o Barão de Paranapiacaba, enxergando um Byron bem mais solene do que se pôde constatar naquelas quadras, onde "o ritmo disfarça um pouco a tristeza" (Barbosa, 1975, p. 248), mas ainda assim rimando conforme o original, traduziu por:

Se os seus melhores dons a vida, ora, te nega

\footnotetext{
${ }^{1}$ V. Um outro Byron no Brasil: a tradução de Paulo Henriques Britto, dissertação de Soeli Staub Zembruski, UFSC, 2008.
} 
AGUSTINI - O pé em que anda o Byron coxo no Brasil da tradução...

Por que suportas inda, um peso, que te dói?

- Da Glória a liça aí tens! - Busca em meio à refrega,

Um sepulcro de herói!

(apud Barbosa, 1975, p. 249)

Depois, em 2007, organizada por Cid Vale Ferreira, outra antologia trouxe, já no título, o tipo de Byron que se resolveu mostrar de novo para a sociedade brasileira: As Trevas e Outros Poemas reúne os mesmos nas mesmas traduções que fizeram a febre, o pesaroso cismar e a melancolia dos ultra-românticos da nação: outra vez o "To Inez" por Fagundes Varela, "She Walks in Beauty" por Franco Meireles, "Darkness" por Castro Alves, que é o poema que Onédia elege como a melhor tradução já feita até então (1912) no Brasil, mais a "Fare Thee Well" pelo Barão de Paranapiacaba, entre outros.

De toda forma, hic et nunc, o Byron satírico, que levou sua influência até Auden e outros; o Byron das "di(trans)gressões metalinguísticas", foi satisfatoriamente sentido nas letras brasileiras atuais, que logo hão de ver também sua obra magna, o Don Juan.

Resta ver neste banquete o que foi guardado cautelosamente para o final: as, como é de se esperar, pi(t)ra(du)ções antropofágicas de Augusto de Campos e a cereja de bolo de Décio.

\section{Um pé coxo na graça da poesia concreta}

A representação alegórica da elegia antiga era manca: composta no dístico elegíaco de um hexâmetro mais um pentâmetro, claramente se constata que do primeiro metro para o segundo está faltando um pé. Hefesto, o deus, por assim dizer, protetor da poesia iâmbica antiga, era manco também: esta poesia iâmbica, de invectiva, de crítica mordaz, que poderia levar o vituperado ao suicídio, elaborada por Arquíloco, Hipônax e, principalmente, Calímaco, era composta, como o próprio nome diz, em pé iâmbico, metro trímetro e outros. Algum tempo depois, não obstante, quebraram o pé final do próprio iambo, nascendo assim um iambo manco: o coliambo. Vale notar, apenas por curiosidade, que Byron, nascido belo como a noite, também nasceu manco como um verso de sátira; ironia do destino, ou sátira do mesmo, não se sabe, nem importa aqui.

\footnotetext{
${ }^{2}$ V. Di(trans)gressões metalinguísticas em Don Juan, de Daniel Lacerda, tese em que se estuda esta obra byroniana como sátira menipeia e a influência que o uso sistemático da metalinguagem nela pode haver exercido sobre a poesia da modernidade.
} 
Mas importa, sim, que a sátira de Byron é filiada à menipeia, o que quer dizer, como conta Daniel Lacerda, citando Bakhtin: "o conteúdo da menipeia é constituído pelas aventuras da ideia ou da verdade no mundo, seja na Terra, no inferno ou no Olimpo" (apud Lacerda, 2008, p. 89). E essa sátira é, no fundo, a mistura de todos os gêneros e elocuções: épico, lírico, elevado, baixo, drama, iambo, reportagem, elegia, bula de remédios e biotônicos etc. Sendo assim, cada tradutor opta pelos trechos que mais lhe aprazem, tendo, destarte, a possibilidade de criar obras completamente díspares e até contrárias na língua e na cultura de chegada, realizando, por fim, um cobiçado objetivo da sátira, que é confundir e baralhar todas as coisas, até não serem outras coisas mais senão as mesmas coisas bagunçadas, com toda a análise psicológica sub-reptícia e crítica acerca das virtudes da alma humana que isto há-de envolver.

Há aqui um amplíssimo campo de trabalho para testar todas as ferramentas já desenvolvidas na área dos Estudos da Tradução, desde o polissistema de Itamar EvenZohar e seus desdobramentos ideados por José Lambert, às análises voltadas ao produto, função ou processo de Holmes que remetem aos primórdios dos Estudos da Tradução no mundo, até mesmo uma abordagem mais lexicológica como a "Teoria das Modalidades" desenvolvida por Francis Aubert e Adriana Zavaglia.

E é agora a parte principal deste artigo que segue:

Décio Pignatari logrou ser um poeta perspicaz, com engenho e audácia. Além de Goethe, Dante, Shakespeare, Burns, Leopardi, Heine e Apollinaire, e além da bela tridução de "A Sesta de Verão de um Fauno", de Mallarmé, e o Rig-Veda, e Horácio, e poetas chineses, traduziu, também, diversas oitavas do Don Juan, que estão publicadas em 31 poetas 214 poemas. São aproximadamente 40 fragmentos entre oitavas completas e trechos de apenas um verso, todos em decassílabos. As oitavas completas foram bem traduzidas, principalmente em seu aspecto formal, nos moldes idênticos aos da boa e velha oitava camoniana, como mais ou menos no original aparece. A única ressalva são seis versos da canção em exortação à independência grega que Décio incluiu ali, e que foi traduzida integralmente também por Péricles Eugênio, de que se comentou acima. Veja-se, como ilustração, a stanza CXVII, que Décio traduziu e inseriu em seu livro, não se sabe por qual razão, com o diferente número de CCXVII:

And Julia's voice was lost, except in sighs,

Until too late for useful conversation;

The tears were gushing from her gentle eyes, 
AGUSTINI - O pé em que anda o Byron coxo no Brasil da tradução...

I wish, indeed, they had not had occasion;

But who, alas! can love, and then be wise?

Not that Remorse did not oppose Temptation;

A little still she strove, and much repented,

And whispering "I will ne'er consent"—consented.

Que em português:

Perdeu-se a voz de Júlia nos suspiros,

Tempo não houve para uma conversa;

Golfavam lágrimas como reis Ciros,

E eu lamentei esse lamento persa.

Motivos houve para tantos tiros?

Lutou um pouco, resistiu bastante,

Disse "Não dou!" - e deu (desconcertante).

(Pignatari, 2007, p. 196)

É impressionante notar que, à exceção de Beppo, que traz em seu fim também uma tradução por Paulo Henriques Britto de uma carta saborosa de Byron, todas as obras byronianas que foram vistas até então estão publicadas em antologias. Esse livro de Décio é ele também uma antologia; no entanto, a opção tradutória dele dentro de Byron se limitou ao Don Juan, que representa uma objetividade sui generis na recepção byroniana brasileira. Agora, como Byron chegou, assim como o Rig-Veda, na poesia concreta, é o que se pergunta em ato contínuo.

No caso de Byron a resposta é fácil: através da obra do "romântico-prémodernista" (Campos, 2009, p. 15) Joaquim de Sousândrade que, com seu Guesa Errante, mais precisamente no trecho denominado "O Inferno de Wall Street", fez a abundante farra poética dos concretos por muito tempo. Com a estrutura tresloucada desse "inferno", e rimas diferentes, e elocução galhofa e complicadíssima, enfim, toda a grande preocupação formal presente neste trecho, os irmãos Campos e Décio se interessaram por ela e trataram de disseminar a obra de Joaquim, dos poucos românticos que liam inglês no século XIX com fluência no Brasil, ou melhor, em Nova York, onde residia. É sem dúvida um dos poucos poetas românticos que sofreram influência direta do Byron satírico don juanesco.

Nessas traduções de Décio Pignatari, bastante condizentes com a poética byroniana, para não se usar o termo "fiéis ao original", expressão tão temida pelos seguidores da "poética da transcriação" (Faleiros, 2012, p. 20), encontra-se uma situação curiosíssima, e que pode levar a afirmar, de um lado, que é uma tradução 
satírica de uma obra satírica, precisamente aliada a uma grande sagacidade, e, no entanto, de outro lado, que é uma dantesca traição, e Décio um grande tradutor traidor; senão, veja-se a última oitava, do Canto I, a CCXXII,:

"Go, little Book, from this my solitude!

I cast thee on the waters- go thy ways!

And if, as I believe, thy vein be good,

The World will find thee after many days."

When Southey's read, and Wordsworth understood,

I can't help putting in my claim to praise-

The four first rhymes are Southey's every line:

For God's sake, reader! take them not for mine.

Que o autor deste artigo traduziu como:

"Sai, Livrinho, da minha solitude!

Segue teu rumo - sobre ondas te taco!

Se teu estilo é bom, como crer pude,

Depois de um tempo o Mundo te achará." Co'

Southey lido, e entendido Wordsworth, atitude

Outra tenho que não de puxa-saco -

De Southey são essas primeiras linhas:

Credo, leitor! não pense que são minhas.

(tradução inédita)

Que Augusto de Campos, do qual se falará na sequência, traduziu por:

"Vai, meu livrinho, de um porto esquecido

Lanço-te às águas, para onde for,

E se houveres de ser bem-sucedido,

O mundo saberá do teu valor."

Com Southey lido e Wordsworth compreendido,

Não posso renunciar em seu favor.

Cito versos de Southey, linha a linha;

Não pense o meu leitor que é obra minha.

(Campos, 2009, p. 43)

E que Décio fez:

"Saia, livrinho, desta solidão"

(Pignatari, 2007, p. 197) 
AGUSTINI - O pé em que anda o Byron coxo no Brasil da tradução...

Sim, Décio Pignatari traduziu apenas este verso da oitava, e com uma fidelidade ao original rigorosamente extremada, para não dizer única, num heroico perfeito, sem nada mais, nem quaisquer comentários ou notas.

Nessa oitava, a última do Canto I, Byron dá a derradeira alfinetada na vítima principal de sua sátira, qual seja, o Poet Laureate Robert Southey, poeta romântico dos tempos do libertino inglês. Cita versos de Southey, inicialmente sem dizer que são de Southey, e termina pedindo, suplicando mesmo, que não confundam aqueles versos de Southey, que iniciaram a oitava, com os seus.

$\mathrm{Na}$ tradução de Décio, como se pode notar, com características semelhantes àquelas do original, traduzida quase palavra por palavra, encontra-se a maior traição possível: ao colocar esses versos de Southey, citados por Byron, no meio dos outros versos de Byron, sem qualquer aviso ou nota, ele, o peralta Décio, faz crer a toda a gente que os versos, debalde a súplica de Byron pedindo que não confundissem com os dele, sejam dele próprio. Cabe lembrar que a primeira edição do livro de Décio foi publicado pelo menos dez anos antes da de Augusto. Isso é uma verdadeira traição traduzindo-se o mais fiel possível: e não deixa de mostrar aí concomitantemente o tino, o requinte e a qualidade de Décio para com a arte da tradução, com seus meandros e suas problematizações, e que remete a um banquete para ser analisado pelos Estudos da Tradução.

Agora, algo sobre Augusto de Campos. Daniel Lacerda, orientado por Décio Pignatari, explica em sua tese o que lhe motivou a feitura dela: perguntara outrora a Augusto sobre o que precisava ser traduzido de poesia para o português e afirma que "não pude deixar de me surpreender ao ouvir a citação do poema byroniano" (Lacerda, 2008 , p. 17). Isto em 2003. Ao que tudo indica, Daniel não entendeu bem que o que faltava era uma tradução, e foi fazer um ponderado e linguisticamente (Jakobson) profundo estudo acerca das metalinguagens e da sátira menipeia em Don Juan, seu doutorado.

Quanto a Augusto, ele mesmo foi traduzir o Don Juan, traduzir não, "tecnomediunizar a poesia de Byron para o português e fazê-la reviver em nossa língua" (Campos, 2009, p. 14), e fê-lo bem, quase psicografando 100 oitavas das 2000 totais. Em mais uma antologia: Byron e Keats - Entreversos, com introdução e pós-tradução. Ali esclarece que, a partir da "re-visão" do poeta Sousândrade começou a se interessar pelo D. Juan. E complementa: "Byron não é um versejador qualquer. Era um artista do 
verso" (2009, p. 11). E ainda elogia as "split-rhymes ou rimas leoninas, em que uma palavra rima com várias outras". Admira-se e louva-se esse sábio interesse de Augusto pelo Don Juan, e com ciência dos interessantes frutos que esta poética pode trazer à cultura brasileira, em breve ver-se-á não apenas uma, mas duas traduções, como será dito mais abaixo, oxalá integrais, do Don Juan para o português do Brasil, com suas belas vogais bem abertas, seu ritmo pausado, suas aprazíveis nasais e tantas outras peculiaridades dessa flor cultivada de início por três raças, atualmente numa nação que abriga todas as raças.

Parece, porém, que quem não concorda muito com Augusto, acerca das grandes qualidades do verso de Byron, é o próprio T. S. Eliot, quando diz, sobre o libertino inglês, de "his schoolboy command of the language" (Eliot, 1957, p. 201) e, arremata: "I cannot think of any other poet of his distinction who might so easily have been an accomplished foreigner writing in English" (p. 201). De todo modo, Eliot termina por elogiar outras qualidades da poesia de Byron, que não especificamente seus versos, mas sua habilidade como narrador, ou sua sátira inteligente, chegando mesmo a exortar que mais estudos acerca dele sejam feitos.

Veja-se, então, outro exemplo da tradução de Augusto de Campos, desta vez de um fragmento esparso encontrado no verso do manuscrito do Canto I:

I wOULD to Heaven that I were so much clay, As I am blood, bone, marrow, passion, feelingBecause at least the past were passed away, And for the future-(but I write this reeling,

Having got drunk exceedingly to-day, So that I seem to stand upon the ceiling) I say-the future is a serious matterAnd so-_for God's sake—hock and soda-water!

Que Augusto fez ser:

Tivesse eu tanto barro em mim pesado, Quanto sangue, ossos, dor, nervos, paixão -

Ao menos o passado era passado -

E o futuro - (eu escrevo em confusão,

Tendo bebido tanto, que, coitado,

Penso pisar o teto em vez do chão)

O futuro não é questão de moda Então - Que diabo! um viva ao vinho e à soda! (Campos, 2009, p. 31) 
AGUSTINI - O pé em que anda o Byron coxo no Brasil da tradução...

Resta frisar de leve que a tecnomediunização de Augusto vem com esquema métrico e rímico idêntico, fidelíssimo, todo colado formal e semanticamente ao original, e que o make it new está num ponto a se fazer de todo coro com o sábio tradutor, e não com o cantor, Álvaro Faleiros:

com efeito, como já em 1983 havia assinalado Jorge Wanderley, a prática tradutória dos irmãos Campos se faz, às vezes, menos radical de que seu próprio discurso, chegando a ser mais conservadora do que aquela praticada por seus predecessores modernistas (...) (Faleiros, 2012, p.29)

Seja como for, inovando ou não, a tradução inegavelmente agrada, e 100 oitavas por Augusto, 40 trechos por Décio, foram traduzidos de uma obra-prima, e é o mais valioso no momento, numa terra onde a Copa do Mundo é mais digna de atenção e de trinta bilhões que um pensamento justo ou o precioso desabrochar de uma nova rima.

Conclui-se esse capítulo com mais dois versos da tradução de Décio, dos belos dois primeiros versos de Byron da oitava CCXVIII do Canto I de Don Juan:

\footnotetext{
What is the end of Fame? ' $t$ is but to fill

A certain portion of uncertain paper:
}

Que busca a fama, ao fim? Só ver inserto

Um certo trecho num jornal incerto.

(Pignatari, 2007, p. 197)

\section{Byron no Brasil: right now}

O Don Juan possui uma dedicatória que ficou por algum tempo desconhecida, porque, como Byron publicara os primeiros Cantos anonimamente, dizia que: "I won't attack the dog in the dark" (Byron, 1970, p. 10). O "cão", no caso, é o poeta Bob Southey. A dedicatória, claro, é irônica, e ali os poetas da região de Lake District, Southey, Wordsworth e Coleridge (a quem Byron dava dinheiro na mesma época), são atacados violentamente, juntamente com Castlereagh, ministro do exterior britânico, que, como no caso de Búpalo com Hipônax na tradição grega, também se suicidaria, não necessariamente pela sátira, mas com um abridor de cartas enfiado na garganta.

Nessa dedicatória, o tom de Byron é um pouco mais elevado que na maior parte do épico, sua linguagem é mais concisa, mais rebuscada, e sua mensagem é mais 
AGUSTINI - O pé em que anda o Byron coxo no Brasil da tradução...

intrincada, repleta de alusões e referências, muitas delas perniciosas. Com a ambiguidade semântica de determinados trechos, com jogos de rimas, e uma imensa gama de táticas de produção de riso, uma tradução dificilmente poderia dar conta de tudo sem o uso de notas. De todo modo, Byron não viu em vida esse trecho publicado, e os leitores de Byron, já bem acostumados com todo o Don Juan, deparar-se-iam somente após dez anos com a dedicatória a Southey, excetuando-se aqueles que a leram em "piratarias e paródias que se aproveitavam da onda de popularidade que propelia o poema" (Schramm Jr., 2012, p. 43) como diz o infracitado Roberto Mário.

No entanto, o Brasil, nada ainda acostumado com o Don Juan, ou, no máximo, conhecedor de alguns trechos pouco representativos dele, além, claro, da 100 oitavas e 41 fragmentos expostos acima, logrou ver em março de 2012, na Revista Literária Nota do Tradutor (n.t.), a própria dedicatória a Southey numa "recreação" de Roberto Mário Schramm Jr., mestrando em Estudos da Tradução da UFSC, que se dedica "à tradução do Don Juan de Byron em versos lusófonos" (2012, p. 43).

Espera-se que sejam publicadas em breve, para o público leitor de língua portuguesa deliciar-se, ambas as traduções de Don Juan que se encontram atualmente sendo cometidas: a de Roberto Mário Schramm Jr. e a de Lucas de Lacerda Zaparolli de Agustini, autor deste artigo; e que ambas tenham qualidade e forneçam novas visões aos novos poetas, além de novos objetos de estudo para os Estudos da Tradução como para a Literatura de um modo geral.

Finalmente, ficam aqui dois breves e irrelevantes excertos acerca das traduções in progress. A de Lucas, que teve apenas um trecho publicado na Revista YAWP 6 e outro na Revista Mallarmargens, seguida da de Roberto Mário: é a oitava XIII da dedicatória, quando Byron usa a imagem da mitologia grega de Ixão girando no Tártaro, numa roda de fogo, para dar a ideia de como seria um discurso do Visconde de Castlereagh:

XIII.

An orator of such set trash of phrase

Ineffably_legitimately vile,

That even its grossest flatterers dare not praise,

Nor foes-all nations - condescend to smile,-

Nor even a sprightly blunder's spark can blaze

From that Ixion grindstone's ceaseless toil,

That turns and turns to give the world a notion

Of endless torments and perpetual motion. 
Estas foram as soluções encontradas por Lucas:

XIII.

Um orador de tão péssimas frases

Não se pode exprimir - vil francamente,

Nem seus bajuladores são capazes

De elogiar-lhe ou sorrir condescendentes, -

Nem fagulhas de asneiras saem vivazes

Da lida árdua de Ixão na pedra ardente,

Que roda e roda e dá ao mundo a noção

De infinda dor, perpétua agitação.

(tradução inédita)

E estas as "recreações” de Roberto Mário:

XIII.

Um narrador acérrimo ao ouvido tão legitimamente demagogo que mesmo ao puxa-saco sai doido (sic) imagine ao inimigo! ó logopeia punida, ausência de sentido! Como Ixion preso à roda de fogo assim gira o discurso do visconde tormento circular pra quem dispõe de (Schramm Jr., 2012, p. 73)

Que o leitor possa analisar por si mesmo a arte e o engenho de uma e outra, bem como ponderar acerca de sua historicização e do propósito dos tradutores e das suas qualidades poéticas intrínsecas, sonoridades e ritmo, além de desfrutar da genial obra-prima Don Juan, é o que se espera.

Conclui-se dizendo que é nesse pé que se encontra o panorama da "instituição Byron", para usar o termo de Augusto de Campos, atualmente no Brasil: em grande produtividade, com um sistema-alvo bem receptivo ao Don Juan, que é, sobretudo, uma sátira de épico, tão ao gosto do "herói sem nenhum caráter brasileiro": belo contraponto de peso ao épico sisudo lusíada camoniano que é imorredouro na poesia em língua portuguesa de há quase meio milênio. 


\section{Referências Bibliográficas}

ACCIOLY, Marcus. Sísifo. São Paulo: Edições Quíron Limitada em convênio com Instituto Nacional do Livro, Ministério da Educação e da Cultura, 1976.

BARBOZA, Onédia Célia de Carvalho. Byron no Brasil: traduções. São Paulo: Ática, 1975.

BYRON, George G. Complete poetical works. Oxford: Oxford University Press, 1970.

. Beppo - uma história veneziana. Trad. Paulo Henriques Britto. $2^{\text {a }}$. edição. Rio de Janeiro: Nova Fronteira, 2003.

Byron - obras. São Paulo: Edições Cultura, 1942.

. Crepúsculo da tarde. Trad. Francisco Otaviano, 2007. Disponível em:

<http://pt.wikisource.org/wiki/O_Crep\%C3\%BAsculo_da_Tarde>. Acesso em: 31 de julho de 2013.

Poesia de lorde Byron. Trad. Péricles Eugênio da Silva Ramos. São Paulo: Art Editora, 1989.

The Works of Lord Byron. Edited by E. H. Coleridge. London: John

Murray, 1903. Disponível em: 〈http://www.gutenberg.org/files/18762/18762-

h/18762-h.htm>. Acesso em: 31 de julho de 2013.

CAMPOS, A. Entreversos - Byron e Keats. São Paulo: Editora Unicamp, 2009.

ELIOT, T.S. On Poetry and Poets. London: Faber and Faber, 1957.

FALEIROS, Álvaro. Traduzir o poema. São Paulo: Ateliê Editorial, 2012.

GUERINI, A.; TORRES, M.H.C.; COSTA, W. (Orgs.) Literatura e tradução: textos selecionados de José Lambert. Rio de Janeiro: 7Letras, 2011.

LACERDA, D. Lord Byron - Poeta crítico: as di(trans)gressões metalinguísticas em Don Juan. 2008. 214 f. Tese - Universidade Federal do Paraná. Curitiba, 2008.

MAROIS, André. Don Juan ou la vie de Byron. Paris: Bernard Grasset Editeur, 1952.

MILTON, John. O Poder da tradução. São Paulo: Ars Poética, 1993 (reeditado como Tradução: Teoria e Prática. São Paulo: Martins Fontes, 1998).

PIGNATARI, Décio. 31 Poetas 214 Poemas - Do Rigveda e Safo a Apollinaire. São Paulo: Ed. Unicamp, 2007.

SCHRAMM JR, R. M. Don Juan - Dedicatória a Robert Southey. Revista Literária em Tradução (n.t.), Florianópolis, v. 1, n. 4, mar. 2012. Disponível em: < http://www.notadotradutor.com/revista4.html $>$. Acesso em: 31 de julho de 2013. 
AGUSTINI - O pé em que anda o Byron coxo no Brasil da tradução...

SOUSA, Maria Luísa Machado. Tempting Demon: The Portuguese Byron. In: CARDWELL, R.A. (Org.). The reception of Byron. New York: Thoemmes Continuum, 2004, v. I, p. 164-187. 